\title{
ANALISIS BIPLOT UNTUK PEMETAAN KARAKTERISTIK KEMISKINAN PADA KABUPATEN/KOTA DI JAWA TIMUR
}

\author{
Gangga Anuraga \\ Dosen Program Studi Statistika FMIPA Universitas PGRI Adi Buana Surabaya \\ E-mail:ganuraga@gmail.com
}

\begin{abstract}
ABSTRAK
Analisis biplot bertujuan memperagakan suatu matriks dengan menumpang tindihkan vektor-vektor yang merepresentasikan vektor-vektor baris dengan vektor-vektor yang merepresentasikan vektor-vektor kolom matriks tersebut. Biplot dilakukan dengan menguaraikan nilai singular atau singular value decomposition (SVD). SVD bertujuan untuk menguraikan nilai singular matrik $\mathbf{Y}$ yang merupakan matrik $\mathrm{X}$ berukuran $\mathrm{n} \mathrm{x} \mathrm{p}$ yang sudah dikoreksi dengan mean, dan kemudian dibangkitkan matriks $\mathbf{G}$ dan $\mathbf{H}$. Hasil analisis faktor diketahui bahwa terbentuk tiga faktor utama yang mewakili variabel asal, yaitu dengan total keragaman yang dapat dijelaskan adalah sebesar 71,427\%. Hasil biplot untuk faktor 1 adalah Kabupaten Jombang, Bangkalan, Blitar, Jember, Tuban, Madiun, Lumajang, Nganjuk, Sumenep, Trenggalek, Sampang, Pamekasan, Probolinggo dimana mempunyai kemiripan persentase rumah tangga yang pernah membeli beras raskin $\left(\mathrm{X}_{3}\right)$ cukup tinggi. Kabupaten Tulungagung, Magetan, Lamongan, Pasuruan, Ngawi, Bojonegoro, Situbondo, Ponorogo, Pacitan, Bondowoso mempunyai karakteristik persentase penduduk miskin usia 15 tahun keatas yang bekerja di sektor pertanian $\left(\mathrm{X}_{2}\right)$ dan persentase rumah tangga miskin yang mendapatkan pelayanan jamkesmas $\left(\mathrm{X}_{15}\right)$ yang relatif tinggi. Dan hasil biplot untuk kombinasi faktor 2 dan 3 dapat diketahui bahwa Kabupaten Sampang, Pamekasan, Sumenep, Kota Probolinggo, Kabupaten Malang, Lumajang, Banyuwangi, Bojonegoro, Pasuruan, Probolinggo, Situbondo, Bondowoso, Jember mempunyai kemiripan karakteristik dalam hal persentase penduduk miskin usia 15 tahun keatas yang tidak tamat $\mathrm{SD}\left(\mathrm{X}_{5}\right)$ yang cukup tinggi. Kesesuaian (goodness of fit) pada biplot faktor 1 sebesar 0,6712 atau 67,12\%, biplot pada faktor 2 dan 3 sebesar 0,7935 atau $79,35 \%$.
\end{abstract}

Kata Kunci : Analisis Faktor, Biplot, Singular Value Decomposition (SVD) 


\section{Pendahuluan}

Analisis Multivariat merupakan suatu metode statistik yang berhubungan dengan lebih dari dua variabel atau terdapat banyak variabel yang diamati dimana antar variabel saling berpengaruh. Analisis faktor merupakan salah satu metode multivariat yang bertujuan untuk mendapatkan sejumlah kecil faktor (komponen utama) yang memiliki sifat mampu menerangkan semaksimal mungkin keragaman data. Metode ini menggambarkan hubungan kovarians dari beberapa variabel dalam sejumlah kecil faktor. Variabel-variabel ini dapat dikelompokkan menjadi beberapa faktor, dimana variabel-variabel dalam satu faktor mempunyai korelasi yang tinggi sedangkan korelasi dengan variabel-variabel pada faktor lain relatif kecil. Faktor-faktor tersebut saling independen dan tiap-tiap faktor dapat diinterpretasikan.

Analisis Biplot diperkenalkan oleh pertama kali oleh Gabriel tahun 1971 dan telah dikembangkan lebih lanjut oleh Gower dan Hand tahun 1996. Analisis ini bertujuan memperagakan suatu matriks dengan menumpang tindihkan vektorvektor yang merepresentasikan vektor-vektor baris dengan vektor-vektor yang merepresentasikan vektor-vektor kolom matriks tersebut. Biplot adalah salah satu upaya menggambarkan data -data yang ada pada tabel ringkasan dalam grafik berdimensi dua. Dengan penyajian seperti ini, ciri -ciri variabel dan objek pengamatan serta posisi relatif antara objek pengamatan dengan variabel dapat dianalisis. Informasi yang diberikan oleh biplot meliputi objek dan variabel. Beberapa informasi penting yang bisa didapatkan dari anaalisis biplot adalah kedekatan antar objek yang diamati, informasi ini dapat dijadikan panduan untuk mengetahui objek yang memiliki kemiripan karakteristik dengan objek lain, posisi relatif objek dan keragaman suatu variabel.

Menurut BPS (2012), pada bulan Maret 2012 penduduk miskin Jawa Timur sebanyak 5,071 juta $(13,40$ persen $)$ atau turun 5,53 persen dibandingkan dengan jumlah penduduk miskin pada bulan Maret 2011 yang mencapai 5,356 juta jiwa (14,23 persen). Dengan wilayah yang luas sekitar \pm $47.922 \mathrm{~km}^{2}$, Provinsi Jawa Timur terbagi atas 29 kabupaten dan 9 kota atau secara administratif terdapat 38 Kabupaten/Kota, sehingga dapat dikatakan berkembang dalam bidang ekonomi dan dapat menjadi potensi pembangunan. Namun demikian, dalam realitanya masih banyak masyarakat yang hidup di bawah persentase garis kemiskinan. Sehingga untuk mencapai terselenggaranya program pengentasan kemiskinan yang optimal, penelitian ini dilakukan untuk mengetahuhi pemetaan karakteristik kemiskinan pada Kab/Kota di Jawa Timur dengan menggunakan analisis biplot berdasarkan faktor (komponen utama) yang terbentuk dalam analisis faktor.

\section{Tinjauan Pustaka}

\subsection{Analisis Faktor}

Analisis faktor adalah salah satu analisis multivariat yang bertujuan untuk mereduksi dimensi data dengan cara menyatakan variabel asal sebagai kombinasi linear sejumlah faktor, sedemikian hingga sejumlah faktor tersebut mampu menjelaskan sebesar mungkin keragaman data yang dijelaskan oleh variabel asal. 
Bila terdapat vektor random $\mathbf{X}$ dengan $\mathrm{p}$ komponen mempunyai mean $\boldsymbol{\mu}$ dan matriks kovarian $\boldsymbol{\Sigma}$, maka model faktor analisisnya (Johnson dan Wichern, 2007) adalah:

$$
\begin{aligned}
& x_{1}-\mu_{1}=\ell_{11} F_{1}+\ell_{12} F_{2}+\ldots+\ell_{1 m} F_{m}+\varepsilon_{1} \\
& x_{2}-\mu_{2}=\ell_{21} F_{1}+\ell_{22} F_{2}+\ldots+\ell_{2 m} F_{m}+\varepsilon_{2} \\
& \ldots \\
& x_{p}-\mu_{p}=\ell_{p 1} F_{1}+\ell_{p 2} F_{2}+\ldots+\ell_{p m} F_{m}+\varepsilon_{p}
\end{aligned}
$$

atau dalam notasi matrik

$$
\boldsymbol{X}-\boldsymbol{\mu}_{p x 1}=\boldsymbol{L}_{p x m} \boldsymbol{F}_{m x 1}+\boldsymbol{\varepsilon}_{p x 1}
$$

dimana: $\mathrm{L}=$ matriks loading faktor

$\ell_{i j}=$ loading dari variabel ke-i pada faktor ke-j

$\mathrm{F}=$ common factors

$\varepsilon_{p}=$ residual ke-p

$\mathrm{i}=$ mean dari variabel ke-i

Komunalitas adalah penjumlahan dari kuadrat loading dari variabel ke-i sampai variabel ke-m, atau dapat ditulis:

$$
h_{i}{ }^{2}=\ell_{i 1}^{2}+\ell_{i 2}^{2}+\ldots+\ell_{i m}^{2}
$$

Hubungan antara varians variabel asal dengan varians faktor dan varians error adalah sebagai berikut:

$$
\begin{aligned}
\operatorname{Var}\left(\mathrm{X}_{\mathrm{i}}\right) & =\text { communality }+ \text { specific variance } \\
& =h_{i}^{2}+\psi_{i} \\
& =\left(l_{i 1}^{2}+l_{i 2}^{2}+l_{i 3}^{2}+\ldots+l_{i m}^{2}\right)+\psi_{i}
\end{aligned}
$$

Dengan metode komponen utama maka diperoleh model (Johnson dan Wichern, 2007) :

$\Sigma=\mathbf{L}^{\prime} \mathbf{L}^{\prime}+\psi$

$$
\left.\Sigma=\mid \begin{array}{llll}
\sqrt{\lambda_{1}} e_{1} & \sqrt{\lambda_{2}} e_{2} & \cdots & \sqrt{\lambda_{m}} e_{m}
\end{array}\right]\left[\begin{array}{c}
\sqrt{\lambda_{1}} e_{1}^{\prime} \\
\sqrt{\lambda_{2}} e^{\prime}{ }_{2} \\
\vdots \\
\sqrt{\lambda_{m}} e^{\prime}{ }_{m}
\end{array}\right]+\left[\begin{array}{cccc}
\psi_{1} & 0 & \cdots & 0 \\
0 & \psi_{2} & \cdots & 0 \\
\vdots & \vdots & & \vdots \\
0 & 0 & \cdots & \psi_{p}
\end{array}\right]
$$

dimana : $\quad \lambda_{i}=$ nilai eigen ke-i dengan $\lambda_{1} \geq \lambda_{2} \geq \lambda_{3} \geq \ldots \geq \lambda_{\mathrm{r}} \geq 0$

$$
\mathrm{e}_{\mathrm{i}}=\text { vektor eigen ke-i }
$$

\subsection{Analisis Biplot}

Rencher (2002) mendiskripsikan bahwa grafik dalam analisis biplot didasarkan pada analisis komponen utama (PCA biplot), yaitu dengan menguaraikan nilai singular atau singular value decomposition (SVD). SVD bertujuan untuk menguraikan nilai singular matrik $\mathbf{Y}$ yang merupakan matrik $\mathrm{X}$ berukuran $\mathrm{n} \times \mathrm{p}$ yang sudah dikoreksi dengan mean, dan kemudian dibangkitkan matriks $\mathbf{G}$ dan $\mathbf{H}$. Misalkan matrik ${ }_{\mathrm{n}} \mathbf{X}_{\mathrm{p}}$ merupakan matriks data dan ${ }_{\mathrm{n}} \mathbf{Y}_{\mathrm{p}}$ merupa- 
kan matriks data yang telah terkoreksi terhadap nilai tengahnya. Maka dengan dekomposisi nilai singular diperoleh :

$Y_{n \times m}=U_{n \times p} L_{p \times p} \quad V_{p \times m}^{\top}$

dimana: $\mathbf{Y}_{\mathbf{n} \times \mathbf{m}}=$ merupakan matrik yang terkoreksi dengan mean misalkan dari suatu matrik data ${ }_{\mathrm{n}} \mathbf{X}_{\mathrm{p}}$

$\mathbf{U}_{\mathbf{n} \times \mathbf{p}}=$ merupakan matrik eigen vektor dari $\mathbf{Y} \mathbf{Y}^{\mathbf{T}}$

$\mathbf{L}_{\mathbf{p} \times \mathbf{p}}=$ berupa diagonal matrik dengan nilai akar eigen value matrik $\mathbf{U}$ dan atau matrik $\mathbf{V}$

$\mathbf{V}_{\mathbf{p} \mathbf{x} \mathbf{m}}=$ merupakan matrik eigen vektor dari $\mathbf{Y}^{\mathbf{T}} \mathbf{Y}$

Persamaan (2.6) dapat pula ditulis sebagai berikut :

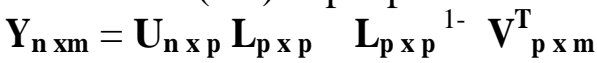

$\mathbf{Y}_{\mathrm{n} \times \mathrm{m}}={ }_{\mathrm{n}} \mathbf{G}_{\mathrm{p}}{ }_{\mathrm{p}} \mathbf{H}_{\mathrm{m}}$

$Y_{n \times m}={ }_{n} G_{p}{ }_{p} H_{m}$. dengan mendefinisikan $\mathbf{G}=\mathbf{U}_{\mathbf{n} \times \mathbf{p}} \mathbf{L}_{\mathbf{p} \times \mathbf{p}}{ }^{\alpha}$ dan $\mathbf{H}=\mathbf{L}_{\mathbf{p} \times \mathbf{p}}{ }^{1-\alpha} \mathbf{V}_{\mathbf{p} \times \mathbf{m}}^{\boldsymbol{\top}}$ dan nilai alpha, $0 \leq \alpha \leq 1$.

Interpretasi dari biplot dapat dilakukan dengan menentukan nilai $\alpha$. Pada umumnya, nilai $\alpha$ dipilih pada nilai ekstrimnya. Nilai $\alpha$ dapat dipilih oleh peneliti dengan pertimbangan untuk lebih menekankan pada baris atau pada kolom matriks $\mathbf{Y}_{\mathbf{n} \times \mathrm{m}}$. Jika diambil $\alpha=1$ artinya peneliti lebih menekankan pada baris matriks $\mathbf{Y}_{\mathbf{n} \times \mathbf{m}}$ (representasi objek). Untuk $\alpha=0$ berarti peneliti lebih menekankan pada kolom matriks $\mathbf{Y}_{\mathbf{n} \times \mathbf{m}}$ (representasi variabel) dan nilai $\alpha=0,5$ dinamakan sebagai biplot yang simetris. Nilai alpha yang digunakan dalam penelitian ini adalah $\alpha=1$, sehingga $\mathbf{G}=\mathbf{U}_{\mathbf{n} \times \mathbf{p}} \mathbf{L}_{\mathrm{p} \times \mathrm{p}}$ dan $\mathbf{H}=\mathbf{V}_{\mathrm{p} \times \mathbf{m}}^{\top}$. Pada Biplot ini masingmasing baris dari matrik data atau objek ditunjukkan oleh titik dalam pasangan nilai komponen utama. Sedangkan kolom ke-i dari matrik data atau variabel ditunjukkan tanda panah. Tingkat kesesuaian (Goodness of fit) dari pendekatan nilai matriks $\mathbf{L}$ dengan rank $=2($ Gabriel, 1971) adalah:

$\left(\lambda_{1}+\lambda_{2}\right) / \sum_{i=1}^{m} \lambda_{m}$

\section{Metodologi Penelitian}

Pada metode penelitian ini akan dibahas mengenai sumber data dan variabel yang digunakan, serta langkah-langkah penelitian.

\subsection{Sumber Data dan Variabel Penelitian}

Data yang digunakan pada penelitian ini merupakan publikasi "Data dan Informasi Kemiskinan Kab/Kota Tahun 2011" hasil olah data triwulanan Survei Sosial Ekonomi Nasional (SUSENAS). Variabel penelitian yang digunakan dalam penelitian ini adalah sebagai berikut :

a. Persentase penduduk miskin usia 15 tahun keatas yang tidak bekerja $\left(\mathrm{X}_{1}\right)$.

b. Persentase penduduk miskin usia 15 tahun keatas yang bekerja sektor pertanian $\left(\mathrm{X}_{2}\right)$.

c. Persentase rumah tangga yang pernah membeli beras raskin $\left(\mathrm{X}_{3}\right)$.

d. Persentase pengeluaran per kapita untuk non makanan $\left(\mathrm{X}_{4}\right)$.

e. Persentase penduduk miskin usia 15 tahun keatas yang tidak tamat SD $\left(\mathrm{X}_{5}\right)$.

f. Angka Melek Huruf penduduk miskin usia 15-55 tahun $\left(\mathrm{X}_{6}\right)$.

g. Angka Partisipasi Sekolah penduduk miskin usia 13-15 tahun $\left(\mathrm{X}_{7}\right)$.

h. Rata-rata lama sekolah $\left(\mathrm{X}_{8}\right)$. 
i. Persentase Perempuan pengguna alat $\mathrm{KB}$ di rumah tangga miskin $\left(\mathrm{X}_{9}\right)$.

j. Persentase Balita di rumah tangga miskin yang proses kelahirannya ditolong oleh tenaga kesehatan $\left(\mathrm{X}_{10}\right)$.

$\mathrm{k}$. Persentase Balita di rumah tangga miskin yang telah diimunisasi $\left(\mathrm{X}_{11}\right)$.

1. Persentase rumah tangga miskin dengan luas lantai perkapita $\leq 8 \mathrm{~m}^{2}\left(\mathrm{X}_{12}\right)$.

m. Persentase rumah tangga miskin yang menggunakan air bersih $\left(\mathrm{X}_{13}\right)$.

$\mathrm{n}$. Persentase rumah tangga miskin yang menggunakan jamban sendiri/bersama $\left(\mathrm{X}_{14}\right)$.

o. Persentase rumah tangga miskin yang mendapatkan pelayanan jamkesmas $\left(\mathrm{X}_{15}\right)$

p. Angka harapan hidup $\left(\mathrm{X}_{16}\right)$.

\subsection{Langkah-langkah Penelitian}

Metode dan tahapan analisis yang akan digunakan dalam mencapai tujuan penelitian adalah sebagai berikut :

a. Mendapatkan statistik deskriptif dari data kemiskinan untuk mendapatkan gambaran mengenai variabel-variabel kemiskinan Kabupten/Kota di Jawa Timur.

b. Melakukan analisis faktor untuk mendapatkan sejumlah faktor yang dapat menjelaskan keragaman data.

c. Melakukan pemetaan karakteristik kemiskinan Kabupaten/Kota di Jawa Timur dengan menggunakan analisis biplot.

d. Menyimpulkan dan menginterpretasikan hasil.

\section{Hasil dan Pembahasan}

\subsection{Statistik Deskriptif Variabel Indikator}

Untuk mengetahui karakteristik kemiskinan di Jawa Timur digunakan analisis statistik deskriptif yang ditinjau dari berbagai indikator sebagaimana ditunjukkan pada Tabel 4.1 sebagai berikut.

Tabel 4.1 Statistik Deskriptif Indikator Kemiskinan di Provinsi Jawa Timur

\begin{tabular}{|c|c|c|c|c|}
\hline Variabel & Min & Max & Mean & $\begin{array}{c}\text { Standar } \\
\text { Deviasi }\end{array}$ \\
\hline $\begin{array}{l}\text { Persentase penduduk miskin usia } 15 \text { tahun } \\
\text { keatas yang tidak bekerja }\left(\mathrm{X}_{1}\right)\end{array}$ & 15.41 & 46.3 & 36.49 & 6.92 \\
\hline $\begin{array}{l}\text { Persentase penduduk miskin usia } 15 \text { tahun } \\
\text { keatas yang bekerja di sektor pertanian } \\
\left(\mathrm{X}_{2}\right)\end{array}$ & 0 & 71.71 & 35.25 & 18.59 \\
\hline $\begin{array}{l}\text { Persentase rumah tangga yang pernah } \\
\text { membeli beras raskin }\left(\mathrm{X}_{3}\right)\end{array}$ & 54.48 & 99.25 & 81.56 & 12.92 \\
\hline $\begin{array}{l}\text { Persentase pengeluaran per kapita untuk } \\
\text { non makanan }\left(\mathrm{X}_{4}\right)\end{array}$ & 34.89 & 55.42 & 44.23 & 5.79 \\
\hline $\begin{array}{l}\text { Persentase penduduk miskin usia } 15 \text { tahun } \\
\text { keatas yang tidak tamat } \mathrm{SD}\left(\mathrm{X}_{5}\right)\end{array}$ & 9.25 & 69.36 & 36.98 & 11.93 \\
\hline $\begin{array}{l}\text { Angka Melek Huruf penduduk miskin usia } \\
15-55 \text { tahun }\left(\mathrm{X}_{6}\right)\end{array}$ & 69.01 & 100 & 90.87 & 6.8 \\
\hline $\begin{array}{l}\text { Angka Partisipasi Sekolah penduduk } \\
\text { miskin usia } 13-15 \text { tahun }\left(\mathrm{X}_{7}\right)\end{array}$ & 49.65 & 100 & 80.71 & 13.84 \\
\hline
\end{tabular}




\begin{tabular}{|c|c|c|c|c|}
\hline Variabel & Min & Max & Mean & $\begin{array}{l}\text { Standar } \\
\text { Deviasi }\end{array}$ \\
\hline - Rata-rata lama sekolah $\left(\mathrm{X}_{8}\right)$ & 4.03 & 11.12 & 7.47 & 1.67 \\
\hline $\begin{array}{l}\text { - Persentase Perempuan pengguna alat KB di } \\
\text { rumah tangga miskin }\left(\mathrm{X}_{9}\right)\end{array}$ & 34.3 & 89.78 & 67.2 & 9.98 \\
\hline $\begin{array}{l}\text { Persentase Balita di rumah tangga miskin } \\
\text { yang proses kelahirannya ditolong oleh } \\
\text { tenaga kesehatan }\left(\mathrm{X}_{10}\right)\end{array}$ & 43.15 & 100 & 85.97 & 16.45 \\
\hline $\begin{array}{l}\text { Persentase Balita di rumah tangga miskin } \\
\text { yang telah diimunisasi }\left(\mathrm{X}_{11}\right)\end{array}$ & 41.1 & 100 & 87.82 & 11.65 \\
\hline $\begin{array}{l}\text { Persentase rumah tangga miskin dengan } \\
\text { luas lantai perkapita } \leq 8 \mathrm{~m}^{2}\left(\mathrm{X}_{12}\right)\end{array}$ & 0 & 67.44 & 17.28 & 13.17 \\
\hline $\begin{array}{l}\text { Persentase rumah tangga miskin yang } \\
\text { menggunakan air bersih }\left(\mathrm{X}_{13}\right)\end{array}$ & 18.27 & 97.53 & 60.01 & 17.68 \\
\hline $\begin{array}{l}\text { Persentase rumah tangga miskin yang } \\
\text { menggunakan jamban sendiri/bersama } \\
\left(\mathrm{X}_{14}\right)\end{array}$ & 13.62 & 96.75 & 66.92 & 22.05 \\
\hline $\begin{array}{l}\text { Persentase rumah tangga miskin yang } \\
\text { mendapatkan pelayanan jamkesmas } \\
\left(\mathrm{X}_{15}\right)\end{array}$ & 9.11 & 90.31 & 62.39 & 15.71 \\
\hline · Angka harapan hidup $\left(\mathrm{X}_{16}\right)$ & 61.06 & 72.19 & 68.24 & 3.18 \\
\hline
\end{tabular}

Hal diatas menunjukkan bahwa terdapat keragaman yang cukup tinggi di beberapa indikator kemiskinan pada Kabupaten/Kota di Jawa Timur. Artinya terdapat kesenjangan antara Kabupaten/Kota di Provinsi Jawa Timur, sesuai dengan karakteristik wilayah itu sendiri.

\subsection{Analisis Faktor}

Tahapan ini digunakan untuk menentukan faktor-faktor utama dari 16 variabel atau mereduksi variabel-variabel sehingga terbentuk faktor utama yang mampu menerangkan maksimum keragaman total data. Tahap pertama dalam analisis ini yaitu melakukan pengujian kelayakan data. Pengujian tersebut diantaranya uji matrik korelasi yang harus merupakan matrik non singular atau dikatakan determinannya tidak nol dan bukan matrik identitas (Uji Bartlett). Uji kecukupan sampling harus dipenuhi juga dalam analisis ini yaitu dengan memakai Uji KMO. Diketahui bahwa nilai determinan matriks korelasinya tidak bernilai nol (2.54) yang berarti matriks korelasinya bukan merupakan matriks singular. Dari uji Bartlett ternyata p-valuenya bernilai 0,000 (kurang dari 0,05) yang memberikan arti bahwa matrik tersebut juga bukan matrik identitas. Untuk menguji kecukupan sampling, digunakan uji Keiser Meiyer Olkin (KMO), dimana nilainya adalah 0,751 . Karena nilai $\mathrm{KMO}>$ dari 0.6 maka dapat dikatakan bahwa sampel sudah cukup dan layak untuk diolah dengan metode ini. Kaiser (1974) dalam Dillon (1978), menetapkan karakteristik pengukuran bahwa nilai KMO sebesar 0,90 adalah sangat bagus, 0,80 bagus, 0,70 cukup, 0,60 kurang, 0,50 jelek dan dibawah 0,50 tidak dapat diterima. Dari beberapa persyaratan yang dibutuhkan, dapat dinyatakan bahwa data yang ada layak untuk diolah lebih lanjut 
dengan menggunakan analisis faktor. Dan berikut adalah nilai keragaman data dalam membentuk faktor utama.

Tabel 4.2 Nilai Karakteristik dan Prosentase Keragaman Faktor

\begin{tabular}{|c|c|c|c|}
\hline Faktor & $\begin{array}{c}\text { Karakteristik Variabel } \\
\text { (Eiegen Value) }\end{array}$ & $\begin{array}{c}\text { Persentase } \\
\text { Keragaman }\end{array}$ & $\begin{array}{c}\text { Kumulatif Persentase } \\
\text { Keragaman }\end{array}$ \\
\hline 1 & 7,578 & 47,362 & 47,362 \\
\hline 2 & 2,656 & 16,597 & 63,959 \\
\hline 3 & 1,195 & 7,468 & 71,427 \\
\hline
\end{tabular}

Dari Tabel 4.2 diketahui bahwa terbentuk tiga faktor utama yang mewakili variabel asal, yaitu dengan total keragaman yang dapat dijelaskan adalah sebesar $71,427 \%$. Selanjutnya untuk menentukan varibel-variabel yang mendu-kung masing-masing faktor utama maka digunakan faktor loading. Faktor loading adalah korelasi antara variabel asal dengan faktor. Faktor loading memberikan informasi tentang variabel mana yang masuk dalam suatu faktor dan seberapa jauh dukungan variabel tersebut terhadap faktor. Penelitian ini menggunakan rotasi tegak lurus varimax untuk meningkatkan korelasi. Rotasi varimax dipilih karena akan memaksimalkan variansi atau keragaman data, sehingga hasil analisis faktor akan lebih mudah diinterpretasikan. Tiga faktor baru yang dihasilkan adalah sebagai berikut :

Faktor 1, faktor ini terdiri atas variabel $\mathrm{X}_{1}, \mathrm{X}_{2}, \mathrm{X}_{3}, \mathrm{X}_{4}, \mathrm{X}_{8}, \mathrm{X}_{12}, \mathrm{X}_{13}, \mathrm{X}_{15}$. Faktor pertama atau komponen utama pertama didominasi dengan variabel-variabel kemiskinan yang berkaitan dengan aspek atau dimensi ekonomi dan kesehatan.

Faktor 2, terdiri atas variabel $\mathrm{X}_{5}, \mathrm{X}_{6}, \mathrm{X}_{9}, \mathrm{X}_{11}$. Faktor kedua atau komponen utama kedua didominasi dengan variabel-variabel kemiskinan yang berkaitan dengan aspek atau dimensi SDM dan kesehatan.

Faktor 3, terdiri atas variabel $\mathrm{X}_{7}, \mathrm{X}_{10}, \mathrm{X}_{14}, \mathrm{X}_{16}$. Faktor kedua atau komponen utama kedua didominasi dengan variabel-variabel kemiskinan yang berkaitan dengan aspek atau dimensi SDM dan kesehatan.

\subsection{Analisis Biplot}

Tahapan selanjutnya dalam penelitian ini yaitu melakukan analisis biplot berdasarkan faktor utama yang terbentuk dalam analisis faktor. Metode ini digunakan untuk mendapatkan pemetaan karakteristik objek Kabupaten/Kota dengan variabel kemiskinan yang terbentuk dalam analisis faktor. Interpretasi dari biplot dapat dilakukan dengan menentukan nilai $\alpha$ pada komponen matrik $\mathbf{Y}_{\mathbf{n} \times \mathbf{m}}=$ ${ }_{n} \mathbf{G}_{\mathrm{p}}{ }_{\mathrm{p}} \mathbf{H}_{\mathrm{m}}$. Pada Biplot ini masing-masing baris dari matrik data atau objek ditunjukkan oleh titik dalam pasangan nilai komponen utama. Sedangkan kolom ke-i dari matrik data atau variabel ditunjukkan tanda panah. Koordinat $\mathrm{h}_{\mathrm{j}}$, merupakan koefisien variabel ke-j dalam dua komponen utama pertama (PCA) dan $\mathrm{g}_{\mathrm{i}}$ dalam plot akan sama dengan posisi lokasi atau obyek ke-i dengan menggunakan dua skor dari dua komponen utama pertama. Berikut adalah hasil biplot untuk faktor 1 dan faktor 2 . 


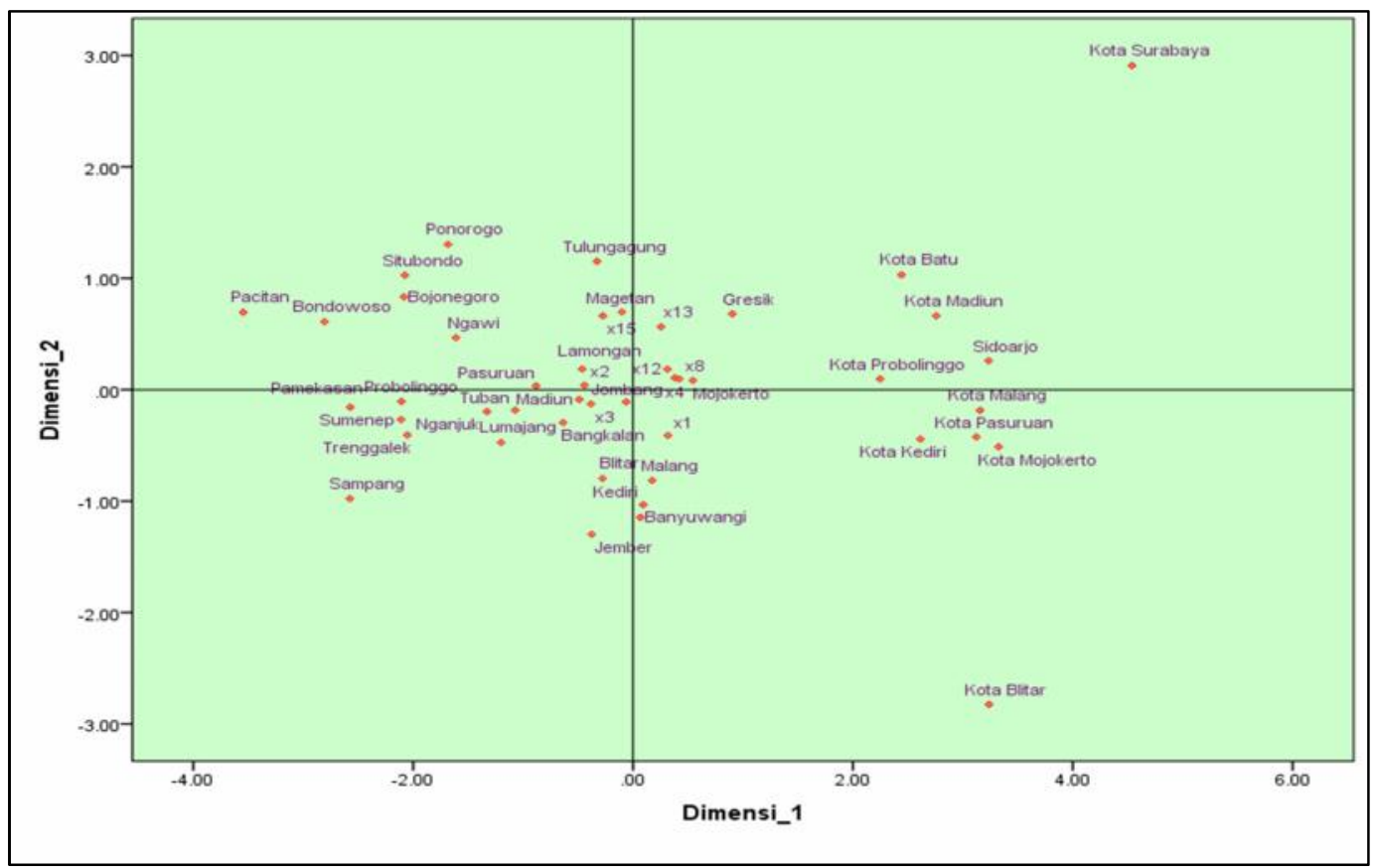

Gambar 4.1 Biplot untuk faktor 1

Hasil analisis biplot pada Gambar 4.1 didapatkan bahwa kedua komponen utama terbesar menjelaskan kesesuaian (goodness of fit) adalah sebesar 0,6712 atau 67,12\%. Kabupaten Gresik, Kota Batu, Kota Madiun, Kota Surabaya, Kota Probolinggo, Kabupaten Sidoarjo mempunyai kemiripan dalam hal karakteristik rata-rata lama sekolah $\left(\mathrm{X}_{8}\right)$, persentase rumah tangga miskin dengan luas lantai perkapita $\leq 8 \mathrm{~m}^{2}\left(\mathrm{X}_{12}\right)$, dan persentase rumah tangga miskin yang menggunakan air bersih $\left(\mathrm{X}_{13}\right)$ yang cukup rendah. Kota Malang, Kota Pasuruan, Kota Kediri, Kota Mojokerto, Kabupaten Mojokerto mempunyai kemiripan dalam hal persentase pengeluaran per kapita untuk non makanan $\left(\mathrm{X}_{4}\right)$ yang cukup tinggi. Sedangkan Kabupaten Malang, Kabupaten Kediri, Kota Blitar dan Banyuwangi mempunyai karakteristik persentase penduduk miskin usia 15 tahun keatas yang tidak bekerja $\left(\mathrm{X}_{1}\right)$ yang cukup tinggi. Kabupaten Jombang, Bangkalan, Blitar, Jember, Tuban, Madiun, Lumajang, Nganjuk, Sumenep, Trenggalek, Sampang, Pamekasan, Probolinggo mempunyai kemiripan persentase rumah tangga yang pernah membeli beras raskin $\left(\mathrm{X}_{3}\right)$ cukup tinggi. Dan untuk Kabupaten Tulungagung, Magetan, Lamongan, Pasuruan, Ngawi, Bojonegoro, Situbondo, Ponorogo, Pacitan, Bondowoso mempunyai karakteristik persentase penduduk miskin usia 15 tahun keatas yang bekerja di sektor pertanian $\left(\mathrm{X}_{2}\right)$ dan persentase rumah tangga miskin yang mendapatkan pelayanan jamkesmas $\left(X_{15}\right)$ yang relatif tinggi. 


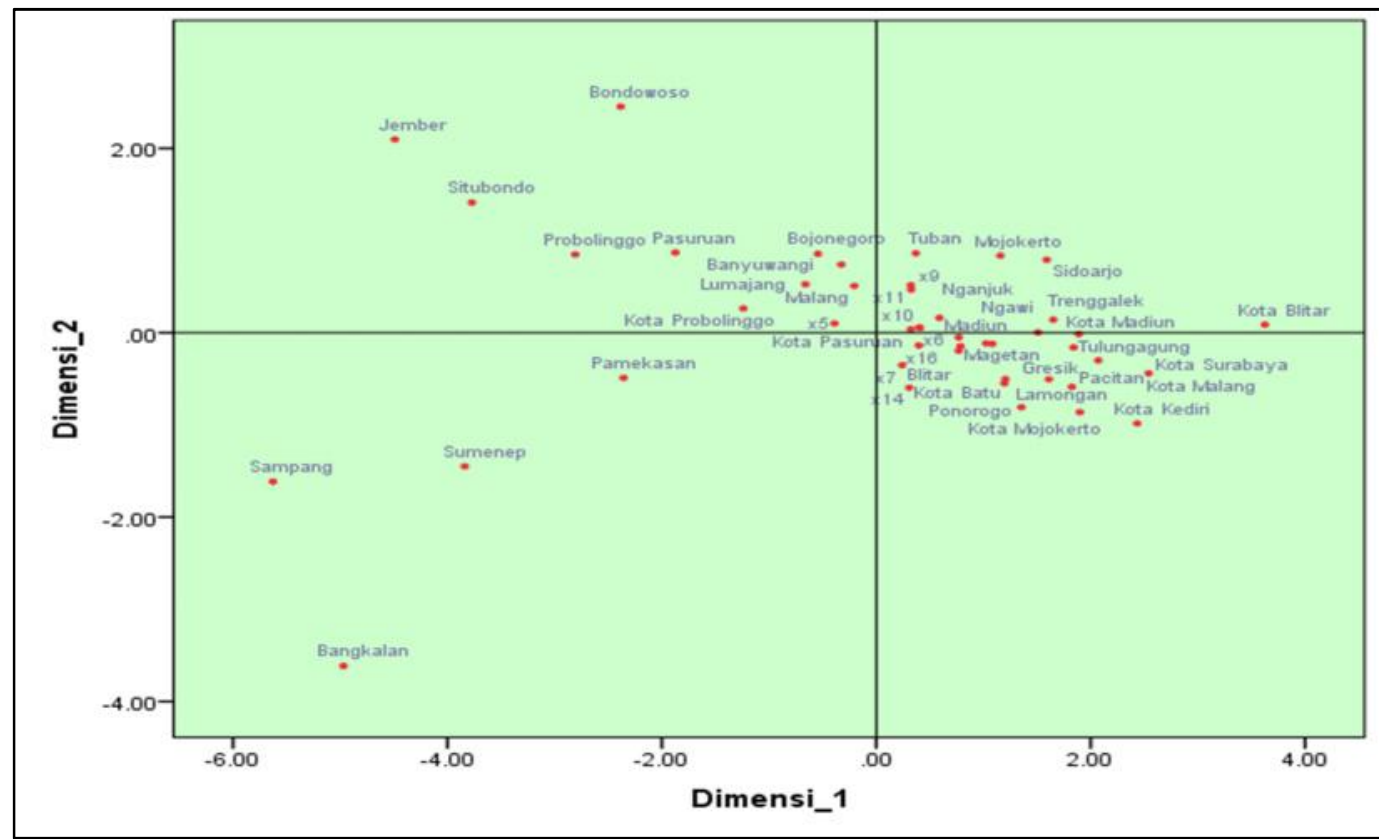

Gambar 4.2 Biplot kombinasi faktor 2 dan 3

Berdasarkan biplot pada Gambar 4.2 didapatkan kedua komponen utama terbesar menjelaskan kesesuaian (goodness of fit) adalah sebesar 0,7935 atau 79,35\%. Kabupaten Tuban, Mojokerto, Sidoarjo, Nganjuk, Ngawi, Trenggalek, Madiun, Kota Madiun, Kota Blitar mempunyai kemiripan dalam hal karakteristik persentase Perempuan pengguna alat $\mathrm{KB}$ di rumah tangga miskin $\left(\mathrm{X}_{9}\right)$, persentase balita di rumah tangga miskin yang proses kelahirannya ditolong oleh tenaga kesehatan $\left(\mathrm{X}_{10}\right)$, persentase balita di rumah tangga miskin yang telah diimunisasi $\left(\mathrm{X}_{11}\right)$ yang relatif tinggi. Sedangkan Kabupaten Tulungagung, Magetan, Gresik, Pacitan, Kota Surabaya, Kota Malang, Kota Kediri, Kota Mojokerto, Kabupaten Ponorogo, Lamongan, Blitar, Magetan, Kota Batu, Kota Pasuruan mempunyai kemiripan karakteristik angka melek huruf penduduk miskin usia 15-55 tahun $\left(\mathrm{X}_{6}\right)$, angka partisipasi sekolah penduduk miskin usia 13-15 tahun $\left(\mathrm{X}_{7}\right)$, persentase rumah tangga miskin yang menggunakan jamban sendiri/bersama $\left(\mathrm{X}_{14}\right)$, angka harapan hidup $\left(\mathrm{X}_{16}\right)$ yang relatif tinggi. Dan untuk Kabupaten Sampang, Pamekasan, Sumenep, Kota Probolinggo, Kabupaten Malang, Lumajang, Banyuwangi, Bojonegoro, Pasuruan, Probolinggo, Situbondo, Bondowoso, Jember mempunyai kemiripan karakteristik dalam hal persentase penduduk miskin usia 15 tahun keatas yang tidak tamat $\mathrm{SD}\left(\mathrm{X}_{5}\right)$ yang cukup tinggi.

\section{Kesimpulan dan Saran}

\subsection{Kesimpulan}

Dari hasil penelitian dengan analisis biplot dapat disimpulkan bahwa daerah kantong dengan karakteristik kemiskinan dalam faktor 1 adalah Kabupaten Jombang, Bangkalan, Blitar, Jember, Tuban, Madiun, Lumajang, Nganjuk, Sumenep, Trenggalek, Sampang, Pamekasan, Probolinggo dimana mempunyai kemiripan persentase rumah tangga yang pernah membeli beras raskin $\left(\mathrm{X}_{3}\right)$ cukup tinggi. Dan untuk Kabupaten Tulungagung, Magetan, Lamongan, Pasuruan, Ngawi, Bojonegoro, Situbondo, Ponorogo, Pacitan, Bondowoso mempunyai 
karakteristik persentase penduduk miskin usia 15 tahun keatas yang bekerja di sektor pertanian $\left(\mathrm{X}_{2}\right)$ dan persentase rumah tangga miskin yang mendapatkan pelayanan jamkesmas $\left(\mathrm{X}_{15}\right)$ yang relatif tinggi. Dan biplot untuk kombinasi faktor 2 dan 3 dapat diketahui juga untuk Kabupaten Sampang, Pamekasan, Sumenep, Kota Probolinggo, Kabupaten Malang, Lumajang, Banyuwangi, Bojonegoro, Pasuruan, Probolinggo, Situbondo, Bondowoso, Jember mempunyai kemiripan karakteristik dalam hal persentase penduduk miskin usia 15 tahun keatas yang tidak tamat $\mathrm{SD}\left(\mathrm{X}_{5}\right)$ yang cukup tinggi. Kesesuaian (goodness of fit) pada biplot faktor 1 sebesar 0,6712 atau 67,12\%, biplot pada faktor 2 dan 3 sebesar 0,7935 atau $79,35 \%$.

\subsection{Saran}

Untuk penelitian selanjutnya dapat juga dilakukan pengembangan indikator terhadap indikator-indikator yang mempengaruhi kemiskinan.

\section{Daftar Pustaka}

Anuraga, G., dan Otok, B. W., (2014), Spasial Structural Equation ModelingPartial Least Square untuk Pemodelan Kemiskinan di Jawa Timur. Tesis : Program Pascasarjana Institut Teknologi Sepuluh Nopember Surabaya.

BPS, (2012). Data dan Informasi Kemiskinan Kabupaten/Kota 2011. Badan Pusat Statistik. Jakarta.

Badan Pusat Statistik, (2012), Perhitungan dan Analisis Kemiskinan Makro Indonesia 2012.

Dillon, W.R dan Goldstein., Matthew, 1984, Multivariate Analysis Method And Aplication, John Willey and Son, New York.

Gabriel, K.R., 1971, The Biplot Graphic Display of Matrices with Application to Principal Componen Analysis, Biometrica, No. 58, Vol 3, 453-467.

Gower, J.C., and Hand, D.J., 1996, Biplot . Chapman and Hall.

Hand, P. J., and Goover, J. C., 1996, Biplots : Monographs on Statistics and Applied Probability 54, Chapman and Hall, Australia

Johnson, R.A. dan Wichern, D.W. (2007), Applied Multivariate Statistical Analysis, Prentice Hall, New Jersey.

Rencher, A.V., 2002, Methods of Multivariate Analysis, John Wiley and Sons, New York. 